\title{
ANTIFUNGAL PROPERTIES OF BRAZILIAN CERRADO PLANTS
}

\section{Lúcia Kioko Hasimoto e Souza ${ }^{1 *}$; Cecília Maria Alves de Oliveira ${ }^{2}$; Pedro Henrique Ferri² ${ }^{2}$ Suzana Costa Santos ${ }^{2}$; Juldásio Galdino de Oliveira Júnior ${ }^{1}$; André Thiago Borges Miranda ${ }^{1}$; Luciano Morais Liãoº ; Maria do Rosário Rodrigues Silva ${ }^{1}$}

${ }^{1}$ Instituto de Patologia Tropical e Saúde Pública da Universidade Federal de Goiás, Goiânia, GO, Brasil. ${ }^{2}$ Instituto de Química da Universidade Federal de Goiás, Goiânia, GO, Brasil

Submitted: October 16, 2001; Returned to authors for corrections: April 04, 2002; Approved: September 24, 2002

\section{SHORT COMMUNICATION}

\begin{abstract}
Ethanolic extracts from leaves of Hyptis ovalifolia, H. suaveolens, H. saxatilis, Hyptidendrum canum, Eugenia uniflora, E. dysenterica, Caryocar brasiliensis and Lafoensia pacari were investigated for their antifungal activity against dermatophytes. The most effective plants were H. ovalifolia and E. uniflora, while Trichophyton rubrum was the most sensitive among the four dermatophytes species evaluated. This study has demonstrated antifungal properties of Brazilian Cerrado plant extracts in "in vitro" assays.
\end{abstract}

Key words: Dermatophytes, antifungal activity, plant extracts, susceptibility tests.

The antifungal agents (griseofulvin, azole derivatives, allylamines and morpholines) used in the treatment of dermatophyte infections, can sometimes have adverse side effects such as gastrointestinal disturbances, cutaneous reactions, hepatotoxicity and leukopenia $(2,6)$. Besides these factors, the acquired resistance to certain antifungals $(3,5,13)$ and the high cost of these synthetic medicines limit the treatment of the dermatophytosis. Plants of Brazilian Cerrado have been broadly used in popular medicine (10). The antifungal activity of extracts and bioactive compounds of Eugenia dysenterica D.C. and Annona crassiflora Mart., against pathogenic fungi Cryptoccoccus neoformans and Candida species were reported by Costa et al. (4) and Silva et al. (11), respectively. The current study was carried out to determine the in vitro antifungal activity of Brazilian Cerrado plant extracts against dermatophytes isolates from different clinical specimens.

Leaves of Hyptis suaveolens (L.) Poit, H. ovalifolia Benth., H. saxatilis A. St. Hil. ex Benth., Hyptidendrum canum (Pohl ex Benth.) Harley (syn.: Hyptis cana Pohl ex Benth.), (Lamiaceae), Eugenia uniflora L., E. dysenterica (Myrtaceae), Caryocar brasiliensis Camb. (Caryocaraceae) and Lafoensia pacari St. Hil. (Lythraceae) were collected in the Brazilian Cerrado, Goiás State, and identified by Prof. Heleno Dias Ferreira (Departamento de Botânica, Instituto de Ciências Biológicas, Universidade Federal de Goiás). Air-dried leaves were powdered and exhaustively extracted with ethanol $95 \%$ at room temperature for 2 days. Extracts were filtered and the solvent removed under reduced pressure at $40^{\circ} \mathrm{C}$. Preliminary antifungal assays were performed using thirty isolates of dermatophytes and leaves extracts at concentration of $1000 \mu \mathrm{g} / \mathrm{mL}$. Fragments $(2 \mathrm{~mm})$ of dermatophytes were inoculated on Mycobiotic agar previously incorporated with extracts, and the antifungal activity was determined by total growth inhibition. $H$. ovalifolia and $E$. uniflora, which showed the best results in the preliminary assays, were chosen for further evaluation of the minimal inhibitory concentration (MIC). The susceptibility test was performed as described by Cáceres et al. (1). The extracts were solubilized in $1 \mathrm{~mL}$ of dimetyl sulfoxide (DMSO) and serially two-fold diluted in Mycobiotic agar medium to obtain a concentration range of 7.8 to $1000 \mu \mathrm{g} / \mathrm{mL}$. Mycobiotic agar

\footnotetext{
* Corresponding author. Mailing address: Laboratório de Micologia, Instituto de patologia Tropical e Saúde Pública, Universidade Federal de Goiás, Rua Delenda Rezende Melo, S/N. Setor Universitário. 74605-050, Goiânia, GO, Brasil. Tel.: (+5562) 209-6127, Fax: (+5562) 202-3066. E-mail: rosario@iptsp.ufg.br
} 
medium containing only DMSO diluted in the same way, which did not influence fungal growth, was included as control. Dermatophytes suspended in $0.85 \%$ sterile physiological saline with tween $80(0.05 \%)$ and standardized at $\mathrm{OD}_{90} 530 \mathrm{~nm}(9)$ were inoculated $(10 \mu \mathrm{L})$ in holes of $3 \mathrm{~mm}$ done in the medium using a Steers inoculator. The inoculated plates were then incubated at $25^{\circ} \mathrm{C}$ for 5 days and the MIC determined as the lowest concentration of the plant extracts able to inhibit any visible fungal growth. Duplicate plates were used for each assay. The susceptibility standard test using terbinafine (10 $\mu \mathrm{g} / \mathrm{mL}$ ), as the positive control, were performed applying the same technique.

Antifungal activity of extracts at the concentration of 1000 $\mu \mathrm{g} / \mathrm{mL}$ was observed in seven out of eight plants tested. $H$. ovalifolia and E. uniflora were the most promising inhibitors, inhibiting completely the growth of the 30 dermatophytes tested. Further evaluation of the minimal inhibitory concentration of these two plants showed that $H$. ovalifolia was the most active, inhibiting 25 out of the 30 dermatophytes at $250 \mu \mathrm{g} / \mathrm{mL}$. In addition, strains of Trichophyton rubrum were the most susceptible as 7 out of the 10 isolates were inhibited in this concentration. E. uniflora showed antifungal activity on 19 out of the 30 isolates at the concentration of $500 \mu \mathrm{g} / \mathrm{mL}$ (Table 1).

Antifungal activity of medicinal plants against some dermatophytes has also been reported by other researchers. Cáceres et al. (1) showed that from 44 aqueous plant extracts, $50 \%$ inhibited the growth of dermatophytes including Microsporum canis and T. mentagrophytes. In addition, the fungitoxicity had been previously described in Annona crassiflora leaf ethanolic extract and essential oil from leaves of E. dysenterica, which were found to inhibit the growth of Candida species and Cryptococcus neoformans $(4,11)$. In the present study, E. uniflora and $H$. ovalifolia appeared very promising for antifungal therapy. Their activity were consistent with there of the pharmacological activity shown by other members of genus Hyptis $(7,8)$. Iwu et al. (7) observed that essential oil of $H$. suaveolens displayed good antimicrobial activity against yeast and filamentous fungi. Among the four species of dermatophytes tested in the present study, T. rubrum was the most sensitive to the plant extracts. This observation has particular interest because T. rubrum is the most common specie of dermatophyte, and represents between 80 to $90 \%$ of all chronic and recurrent infections (12). This species also shows resistance to the antifungal product used for the dermatophytosis treatment (13). Our findings indicate that traditional medicines remain a valuable resource for the discovery of natural pharmaceutical products.

\section{ACKNOWLEDGEMENTS}

The authors are indebted to CNPq (\#520769/99-6), PADCT III (\#620166/97-5) and FUNAPE/UFG for financial support. Thanks are also due to CNPq/PIBIC for fellowships to J.G.O. Jr. and A.T.B.M.

\section{RESUMO}

\section{Propriedades antifúngicas de plantas do Cerrado brasileiro}

A atividade antifúngica de extratos etanólicos de folhas de Hyptis ovalifolia, $H$. suaveolens, $H$. saxatilis, Hyptidendrum canum, Eugenia uniflora, E. dysenterica, Caryocar brasiliensis e Lafoensia pacari sobre isolados de dermatófitos foi verificada. Os extratos mais ativos foram os de H. ovalifolia e E. uniflora, enquanto que Trichophyton rubrum foi o dermatófito mais sensível a ação das plantas. Estes dados demonstram as propriedades antifúngicas de plantas do Cerrado em ensaios in vitro.

Palavras-chave: Dermatófitos, atividade antifúngica, extratos de plantas, teste de suscetibilidade.

Table 1. Cumulative percentage inhibition of dermatophyte isolates after treatment with different concentrations of $\mathrm{H}$. ovalifolia and E. uniflora ethanolic extracts.

\begin{tabular}{|c|c|c|c|c|c|c|c|c|c|}
\hline & & \multicolumn{8}{|c|}{ Concentration $(\mu \mathrm{g} / \mathrm{mL})$} \\
\hline \multicolumn{2}{|c|}{ Plants/Dermatophytes ( $\mathrm{N}^{\circ}$ of strains) } & 7.8 & 15.6 & 31.2 & 62.5 & 125 & 250 & 500 & 1000 \\
\hline \multirow{4}{*}{ 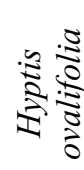 } & M. canis (5) & & 20 & 20 & 20 & 40 & 100 & & \\
\hline & M. gypseum (5) & & & & 20 & 20 & 60 & 60 & 100 \\
\hline & T. rubrum (10) & & & & 70 & 70 & 100 & & \\
\hline & T. mentagrophytes (10) & & & & & & 70 & 70 & 100 \\
\hline \multirow{4}{*}{ 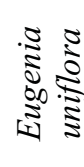 } & M. canis (5) & & & & & & & 40 & 100 \\
\hline & M. gypseum (5) & & & & & & & 60 & 100 \\
\hline & T. rubrum (10) & & & & & & & 100 & \\
\hline & T. mentagrophytes (10) & & & & & & & 40 & 100 \\
\hline
\end{tabular}




\section{REFERENCES}

1. Cáceres, A.; López B.; Juárez, X.; Aguila, J.; García, S. Plants used in Guatemala for the treatment of dermatophytic infections. 2. Evaluation of antifungal activity of seven American plants. $J$. Ethnopharmacol., 40: 207-213, 1993.

2. Carazo, J.L.S.; Losada, L.O.; Sanjuan, V.P. Tratamiento actual de las micosis superficiales. Rev. Iberoam. Micol., 16: S26-S30, 1999.

3. Chee-Leok, G.; Young Kwang, T.; Kamarudim, B.A.M.; Chew, S.S. In vitro evaluation of griseofulvina, ketoconazole, and itraconazole against various dermatophytes in Singapore. Int. J. Dermatol., 33 733-737, 1994.

4. Costa, T.R.; Fernandes, O.F.L.; Santos, S.C.; Oliveira, C.M.A.; Lião, L.M.; Ferri, P.H.; Paula, J.R.P.; Ferreira, H.D.; Sales, H.N.; Silva, M.R.R. Antifungal activity of volatile constituents of Eugenia dysenterica leaf oil. J. Ethnopharmacol., 72: 111-117, 2000.

5. Del Palacio, A.; Cuétara, S.; González, R.A.; Valle, A. Reservas sobre la utilización de terbinafina (Lamisil) en tiñas del cuero cabelludo por Microsporum canis. Act. Dermosif., 89: 317-318, 1998.

6. Gupta, A.K.; Del Rosso, J.Q.; Lynde, C.W.; Brown, G.H.; Shear, N.H. Hepatitis associated with terbinafine therapy: Three case reports and a review of the literature. Clin. Exp. Dermatol., 23: 64-67, 1998.
7. Iwu, M.M.; Ezeugwu, C.O.; Okunji, C.O. Antimicrobial activity and terpenoids of essential oil of Hyptis suaveolens. Int. J. Crude. Drug. Res., 28: 73-76, 1990.

8. Lentz, D.L.; Clark, A.M.; Hufford, C.D.; Meurer-Grimes, B.; Passreiter, C.M.; Cordero, J.; Ibrahimi, O.; Okunade, A.L. Antimicrobial properties of Honduran medicinal plants. $J$. Ethnopharmacol., 63: 253-263, 1998.

9. Lima, E.O.; Gompertz, O.F.; Giesbrecht, A.M.; Paulo, M.Q. In vitro antifungal activity of essential oils obtained from officinal plants against dermatophytes. Mycoses, 36: 333-336, 1993.

10. Septimio, L.R. Fitoterapia baseada em ervas medicinais do cerrado. SIPE. Ministério da Agricultura. Brasília, 1994.

11. Silva, M.V.; Costa, T.R.; Costa, M.R.; Ferreira, E.C.; Fernandes, O.F.L.; Santos, S.C.; Lião, L.M.; Ferri, P.H.; Paula, J.R.; Ferreira, H.D.; Silva, M.R.R. Growth inhibition effect of Brazilian cerrado plant extracts on Candida species. Pharm. Biol., 39: 138-141, 2001 .

12. Torres-Rodrigues, J.M.; Madrenys-Brunet, N.; Urrea-Arbeláez, A.; López-Jodra, O. Terbinafina por via oral en el tratamiento de la tinea unguium de los pies. Eficacia entre 12 y 14 semanas de tratamiento. Rev. Iberoam. Micol., 15: 160-162, 1998.

13. Zaias, M.D.; Gerbert-Rebell, M.S. Chronic dermatophytosis syndrome due to Trichophyton rubrum. Int. J. Dermatol., 35: 614-618, 1996. 